\title{
セルロース系繊維の防縮加工剤としての リン酸アミド類の適性*
}

\begin{tabular}{|c|c|c|c|c|}
\hline 日東紡績加工研究所 & 笹 & 倉 & 忠 & 雄 \\
\hline 日東紡績加工研究所 & 穴 & 迫 & 康 & \\
\hline 日東紡績加工研究所 & 藤 & 川 & 達 & 志 \\
\hline 日東紡績加工研究所 & 大 & 門 & & \\
\hline 京都工芸繊維大学工芸学部 & 老 & 田 & 達 & 牛 \\
\hline 京都工芸織維大学工芸学部 & 清 & 水 & 富 & \\
\hline 京都工芸繊維大学工芸学部 & 林 & & 良 & \\
\hline
\end{tabular}

\section{Design of Effective Shrink-Proofing Modifications of Cellulosics by Phosphoryl Amides*}

\author{
Tadao Sasakura**, Yasuyuki Anasako**, Tatsusi Fujikawa**, Masaru Daimon**, \\ Tatsuo Oida***, Tomio Shimizu ${ }^{* * *}$ and Yoshiyuki Hayashi***
}

\begin{abstract}
In the design of effective shrink-proof modification of cellulosics, the factors to be considered include cost, efficiency, durability of shirink-proofing, and effect of the treatment on other fabric properties. A number of the finishings of rayon were performed with the use of crude phosphoryl amides prepared from the reaction of phosphoryl chloride with a saturated solution of ammonia in methanol (method A), from the reaction of ammonia with a solution of phosphoryl chloride (or chloro-phosphazene) in a solvent such as chlorinated alkanes or arenes, and ethers (method B).

The most eminent characteristics in the use of the phosphoryl amides prepared by method A were the more efficient durable shrink-proofing and fastness against chlorine damage than the case of method $\mathrm{B}$. The increase in the amounts of methoxy-substituted products at high reaction temperatures in metod A caused the decreases in efficiency of shrink-proofing and whiteness of the treated rayon.

Presence of water in methanol afforded hydroxy-substituted products and ammonium phosphate derivatives. However, the crude phosphoryl amides prepared in the presence of a small amount of water gave more desirable shrink-proofing, probably due to the catalytic effect of ammonium phosphate formed for the shrink-proofing. The optimum amount of water in the methanol for shrink-proofing was about $10 \%$. Sodium borohydride treatment before the shrink-proofing increased the whiteness of fabrics.
\end{abstract}

(Received October 30, 1992)

(Accepted for Publication July 12, 1993)

*この報文を「リン酸アミド類を用いるセルロース繊維の防縮加工に関する研究（第 2 報）」とする

*Study on the Shrink-proof Finishing of Cellulosics by Phosphoryl Amides (Part 2)

**Nitto Boseki Co., Nishikuwazu, Itami

***Faculty of Engineering and Design, Kyoto Institute of Technology, Matsugasaki, Kyoto 
メタノールのアンモニア飽和溶液（A 法）および従来法での溶媒を用いて得られた粗製リン酸アミド（B 法）を用いてセルロ 一ス系布帛の加工を行い，その加工布の物性について比較検討した． A 法で得られたリン酸アミドによる加工布は B 法のそれ より防縮性, 耐塩素傷害性が著しく優れ, さらに非ホルムアルデヒド系グリオキサール・尿素樹脂に比へ防縮性に優れ, 曲げ特 性值が低く，風合いが極めて柔らかであった． A 法の副生成物であるメトキシ基を有する化合物の含有率は合成時の反応温度が 高くなると増加するが, 反応温度の高い条件で合成した粗製リン酸了ミドを用いた加工布は低温での合成品に比べて防縮性, 布 の白度いずれも低下した. A 法のアンモ二ア飽和溶液に水を添加したとき得られる粗製リン酸アミドについて, 水の添加量と加 工布の性質との関係について検討した. 水を少量添加すると防縮性は向上するが, 最適の水添加量が存在した. 水を添加すると 粗製リン酸アミド中にかなりリン酸アンモニウムが生成した。リン酸アンモニウムの加工触媒作用について検討した。リン酸ア ンモニウムを加工剤に添加すると防縮性, 而塩素傷害性, 白度のいずれも向上した. 水素化ホウ素ナトリゥムで加工布を前処理 すると防縮加工布の白度は改善された。

(平成 4 年 10 月 30 日受付)

(平成 5 年 7 月 12 日審查終了)

\section{1. 緒 言}

繊維の本来の目的は身体の保護であり，従って， 肌に触れたときの感触, 風合いおよび寸法安定性は 強度とともに繊維の物性で最も重視される点であ る. 天然緘維はこれらの点でかなり優れた衣料材料 であるが，寸法安定性の点では合成繊維に比べて見 劣りする．防縮性および防しわ性に関する天然瀻維 の改質は，これまで多くの研究が行われた割には十 分な成果が得られていない。

セルロースの防縮性, 防しわ性などを向上させる ための加工剂として，ホルムアルデヒド系樹脂が用 いられている(1 6).これらの樹脂を用いた加工布は消 費段階でホルムアルデヒドを遊離し，衣料公害の原 因となっている．グリオキサール系尿素誘導体の非 ホルムアルデヒド樹脂が市販されているが，防縮・ 防しわ効果は極めて少ない，また，非ホルムアルデ ヒド系の加工剤として多塩基酸が研究されている が，コスト，操業性などの問題のため，まだ工業化 されるまでには至っていないて

アミノホスファゼンおよびリン酸アミドはセルロ

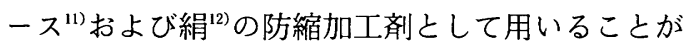
できる.しかし，これらのリンのアミノ化物により 防縮効果が得られる機構は, 未だ解明されていな い. アミノホスファゼンが加工条件下で水の付加お よびリン酸アミドへの加水分解が起きること列， へ キサアミノシクロトリホスファゼン (HAP) よりリ ン酸トリアミド (PTA) の方が防縮加工剂として好 ましいこと．PTA はアミドとアルコールとの交換 反応でリン酸エステルを生成すること, リン酸アミ ドの反応には酸および塩基が触媒として有効である ことなどから，リンのアミノ化物のアミド交換によ る架端が繊維の防縮に寄与しているとの仮説が考え
られる ${ }^{17)}$

前報 ${ }^{13)}$ にいて，メタノールのアンモニア飽和溶 液と塩化ホスホリルとの反応（A 法）で効率よくリ ン酸アミドが得られることを報告した，従来の合成 法（B 法）は不活性溶媒例えば八ロゲン系溶媒, エ ーテルなどに塩化ホスホリルを溶解し，この溶液に アンモニアを吹き込む方法が用いられている. A 法 を用いて得られた粗製リン酸アミド化合物は，B法 から得られた化合物に比べ, 未反応塩素を含んだ化 合物が存在しないこと, PTA 含有率が高いこと, 副 反応生成物であるメトキシ基を有する化合物が存在 するがその含有率は少なく数\%以下であることなど が明らかになった ${ }^{13)}$. 回収メタノールは吸湿してい る可能性があるので, メタノールに水を添加した系 での $\mathrm{A}$ 法リン酸アミドの合成も検討した。 また， A 法および B 法で得られたリン酸アミドの組成はか なり異なっており, それらの防縮加工剂適性につい て比較検討した. さらに, 非ホルムアルデヒド系樹 脂であるグリオキサール系尿素誘導体との比較検討 あ行った.

塩化アンモニウムを含む加工剤で綿を処理する と, 黄変によって白度が低下するのが普通である.

リン酸アミドによる防縮加工においても白度の低下 がみられるが，この解決法も見出したので報告す る.

\section{2. 実 験}

\section{1 加工剂}

市販品の工業用リン酸アミドおよび工業用アミ， ホスファゼンはニチメンから提供されたものをその まま用いた。へキサアミノシクロトリホスファゼン (HAP) は文献 ${ }^{14)}$ 従って合成した。 
Table 1 Effects of finishes on fabric physical properties

\begin{tabular}{|c|c|c|c|c|c|c|c|}
\hline \multirow{2}{*}{ Reagent } & \multirow{2}{*}{$\begin{array}{l}\text { Add-on } \\
(\%)\end{array}$} & \multicolumn{2}{|c|}{$\begin{array}{l}\text { Shrinkage(\%) } \\
\text { after laund. }\end{array}$} & \multirow{2}{*}{$\begin{array}{l}\text { Chlorine } \\
\text { damage } \\
\text { (rating) }\end{array}$} & \multirow{2}{*}{ Whiteness } & \multicolumn{2}{|c|}{$\begin{array}{l}\text { Bending } \\
\text { properties }^{(1)}\end{array}$} \\
\hline & & $\mathrm{W}^{a)}$ & $F^{b)}$ & & & B & $2 \mathrm{HB}$ \\
\hline control & - & 13 & 7 & 5 & 140 & 0.0283 & 0.0140 \\
\hline Method A & 10 & 7 & 5 & $4-5$ & 137 & - & - \\
\hline \multirow[t]{3}{*}{ Amides } & 15 & 5 & 4 & 4 & 134 & 0.0282 & 0.0115 \\
\hline & 20 & 4 & 2 & 4 & 131 & - & - \\
\hline & 30 & 3 & 1 & 4 & 129 & - & - \\
\hline Method B & 10 & 7 & 5 & 3 & 137 & - & - \\
\hline \multirow[t]{3}{*}{ Amides } & 15 & 6 & 4 & $2-3$ & 134 & 0.0285 & 0.0116 \\
\hline & 20 & 6 & 3 & 2 & 132 & - & - \\
\hline & 30 & 6 & 3 & 2 & 128 & - & - \\
\hline $\mathrm{PA}^{d)}$ & 20 & 6 & 4 & $2-3$ & 131 & 0.0290 & 0.0121 \\
\hline $\mathrm{HAP}^{e}$ & 20 & 6 & 3 & 2 & 132 & 0.0289 & 0.0121 \\
\hline $\operatorname{AP}^{f \prime}$ & 20 & 6 & 3 & $1-2$ & 128 & 0.0311 & 0.0129 \\
\hline
\end{tabular}
a) Warpwise. b) Fillingwise.
c) Average of warp and filling.
d) Commercial phosphoryl amide.
e) Hexaaminocyclotriphosphazene.
f) Commercial aminophosphazene.

\section{A 新規リン酸アミドの合成法 $(A \text { 法 })^{13)}$}

$0^{\circ} \mathrm{C}$ 以下に冷却したメタノール $(100 \mathrm{ml})$ にアンモ ニアガスを吹き込み飽和した．この飽和溶液にさら にアンモニアを通しながら擋汼しつつ, $0 \sim 5{ }^{\circ} \mathrm{C}$ 溶 液温度で塩化ホスホリル $(15.3 \mathrm{~g}, 0.1 \mathrm{~mol})$ を圧入 した. 圧入終了後, さらに $0^{\circ} \mathrm{C} て ゙ 30 \mathrm{~min}$ 間擋拌した. 反応液を室温に戻したのち, 減圧下でメタノールを 留去して, リン酸アミドと塩化アンモニウムとの混 合物である粗製リン酸アミドを得た.

\section{B 従来法によるリン酸アミドの合成 (B 法)}

エーテル $(100 \mathrm{ml})$ に塩化ホスホリル $(15.3 \mathrm{~g}, 0.1$ $\mathrm{mol}$ ）を溶解し，擋拌しながら $5^{\circ} \mathrm{C}$ 以下でアンモ二 アガス ( $1.2 \mathrm{~mol}$, 化学量論の 2 倍量)を $3 \mathrm{hr}$ で吹き 込んだ，吹き込み終了後，滅圧下でエーテルを留去 し粗製りン酸アミドを得た。

\section{1・A の条件で水を溶媒に添加して合成したり} ン酸アミドおよび反応温度を変えて合成したりン酸 アミドについてもその加工剂適性を検討した，粗製 リン酸アミド類は約 $37 \%$ のン酸アミドと約 $63 \%$ の 塩化アンモニウムを含む. 一方, アミノホスファゼ ンは約 $58 \%$ の塩化アンモニウムを含む. 冷却した塩 化ホスホリル $(1 \mathrm{~mol})$ にメタノール (1mol) を滴下 反応して得たジクロロリン酸メチルを A 法と同様 に処理して得たジアミドリン酸メチルも比較用加工 剤として使用した.

\section{2 試 薬}

工業用水素化ホウ素ナトリウム（モートン・イン ターナショナル社) を, その他の試薬はすべて試薬 1 級（和光純薬）を用いた。

\section{3 加工布}

普通レーヨンはスフモス生機（9たて $30 \mathrm{~s} ・ 68$ 本/ in, ょこ $30 \mathrm{~s} ・ 68$ 本/in）を山東鐵工所製高圧精練機 で毛焼, 糊抜, 精練および漂白を行い, ドラム式乾 燥機で乾燥した。表 5 で使用したレーヨンはこのま ま, 表 1〜4で使用したレーヨンはさらに L ボック ス機で水素化ホウ素ナトリウム処理を行い, ドラム 乾燥機で乾燥した後, テンター式仕上げ機を用い下 蛍光処理を行ったものを用いた. 表 5 で用いた試験 布，ポリノジックはキャリコ（たて，30s・75本/in, よこ30s・75本/in），木綿は金巾（たて $30 \mathrm{~s} ・ 69$ 本/ in，よこ $30 \mathrm{~s} ・ 69$ 本/in）をそれぞれ精練後，テンタ 一式仕上機を用いて下蛍光処理を行ったものを用い た.

\section{4 防縮加工方法}

ピン付木枠の大きさの長方形を描いた実験2.3記 載の普通レーヨンを必要量の加工剂を溶解して調整 した加工液に浸漬し，ピックアップ約100\%に絞液 
した後, レーヨンに画いた長方形と木枠のピンとを 合わせてレーヨンを木枠にセットし，100ㄷて 5 $\min$ 間予備乾燥した。 $160^{\circ} \mathrm{C}$ にて $3 \mathrm{~min}$ キュアリン グを行った. この布を $60^{\circ} \mathrm{C}$ 湯で $3 \mathrm{~min}$ 間洗い, さ らに常温の水で $1 \mathrm{~min}$ 間洗い，これをそれぞれ 3 回 行った後, 上記と同様の方法で木枠に固定して乾燥 して加工布を得た. 表 1〜4の比較布（control）は 加工剂を用いずに上記と同様に処理した。

防縮効果は下記2.6の洗濯収縮率で表した。

\section{5 水素化ホウ素ナトリウム処理}

各所定濃度の水素化ホウ素ナトリウム水溶液に加 工布を $95^{\circ} \mathrm{C}$ で $10 \mathrm{~min}$ 間浸漬後, $60^{\circ} \mathrm{C}$ の温水で 3 回洗 い乾燥した。

\section{6 加工布物性值の測定}

洗濯収縮率は JIS L0217 103法に準じて洗濯を 行い, タンブラー乾燥したあので測定した. 表 1〜4 には 5 回洗濯, 乾燥を繰り返した後の洗濯収縮率を 示した.

塩素傷害は JIS L1041(1983)5.4項に従って測定 した。

白度は JIS 1013(1981)7.20項 B 法に従って測定し た.

曲げ特性は “風合い評価の標準化と解析”第 2 版 （日本繊維機械学会 風合い計量と規格化研究委員 会発行) 27ページ記載の方法 (KES) に従って B (gf - $\left.\mathrm{cm}^{2} / \mathrm{cm}\right)$ および $2 \mathrm{HB}(\mathrm{gf} \cdot \mathrm{cm} / \mathrm{cm})$ を求めた

銅価は JIS P-8101(1961)5.6ページの方法に従 って測定した.

\section{3. 実験結果と考察}

B 法によるアミノホスファゼンおよびリン酸アミ ドは完全なアミノ化が困難なため未反応の塩素を含 有しやすい ${ }^{13)}$. 従って, 防炎加工剂として利用する 場合においても, 加工布の風合いが硬いこと, 黄変 し白度が低下すること, 塩素傷害性が大きいことな ぞが欠点で実用化の障害になっている，特に，洗濯 により加工布から窒素分が脱離することによる防炎 性の低下である. 防炎加工ではリンが $2 \%(\mathrm{dwf})$ 程 度付着していることが必要である。，一方，防縮加工 ではリンは防炎加工の半分以下の反応量で目的が達 せられるとともに，加工布の防縮性は洗濯によって あ低下しない" ${ }^{11)}$ ：ここで用いた加工剤はいずれも60 〜 70\%の塩化アンモニウムを含み，有効分 $37 〜 42 \%$
のうちリンの含有量は33〜40\%である.

\section{1 防縮加工剂としての適性比較}

$\mathrm{A}$ 法によるリン酸アミド，B 法によるリン酸アミ ト，防炎加工剂として市販されている工業用リン酸 アミドおよびアミノホスファゼンを用いて防縮加工 を行い, 得られた加工布の性能から加工剂としての 適性の比較検討を行った. その結果を表 1 に示す。

值はいずれあ10サンプルの平均值である.

A 法リン酸アミドはいずれのリンアミノ化物よ りも全般に良好な加工効果を, また，グリオキサー ル系尿素樹脂誘導体より極めて優れた防縮効果を示 した. 市販品防炎剤はいずれも $\mathrm{B}$ 法りン酸アミドの それとほぼ同じ程度の防縮加工効果を示した。

ピックアップ率を約100\%になるように絞液して いるので加工剂の付着量 (Add-on) は加工剂調整 液の濃度をそのまま加工布への付着量として表し た. 表 1 には洗濯, 乾燥を 5 回繰り返した後の洗濯 収縮率を示したが，この収縮率と加工剂付着量との 関係をみると，A 法リン酸アミドを用いた場合は付 着量が増加するとともに収縮率は減少し，測定誤差 範囲内で収縮率 0 に近い值となった。一方，B 法り ン酸アミドのそれは付着量10\%ぐらいから収縮率の 低下はみられなくなる。而塩素傷害性も A 法リン 酸アミドによる加工布の方が良好で，B法のそれに 比べ 2 ポイント, さらに市販品リン酸アミドより 2.5 ポイント高い. A 法リン酸アミドにより塩素傷 害が改善された理由はA 法リン酸了ミドからは塩 素傷害の原因となるイミドリン酸タイプの副生成物 が少ないためと考えられる. 曲げ特性の B 值は単位 長さ当りの曲げ剛性, $2 \mathrm{HB}$ はヒステリシスを表す. $\mathrm{B}$ 法リン酸アミドを用いた加工布は尿素ーホルマリ ン樹脂などのベース樹脂を用いた加工布に比べ格段 に柔らかいが，A 法リン酸アミドの方がさらに柔ら かい加工布を与えた。

以上の結果から $\mathrm{A}$ 法リン酸アミドは液体アンモ ニア中で長時間（約 $48 \mathrm{hr}$ ）反応して合成したリン酸 トリアミド'16)とほぼ同様の優れた加工性能を有し， ジメチルスルホキシド中での絹の防縮加工とほぼ同 じ結果であった ${ }^{17)}$. レーヨンおよび絹の防縮性付与 のためには約 $100 \%$ の膨潤度において，防縮に効果 的な構造部分にリン酸アミドが浸透し，そこで架橋 反応が起きることが有効であると考えられる ${ }^{15)}$. こ の架橋反応はレーヨンの場合, 水酸基とリン酸アミ ドのアミド交換反応と思われる. リン酸アミドの自 
Table 2 Effect of preparation temperature of phosphoryl amides on fabric properties

\begin{tabular}{|c|c|c|c|c|c|c|c|}
\hline \multirow{2}{*}{$\begin{array}{l}\text { Reaction } \\
\text { Temp. } \\
\left({ }^{\circ} \mathrm{C}\right)\end{array}$} & \multirow{2}{*}{$\begin{array}{l}\text { Content (\%) of } \\
\text { methoxy-subst. } \\
\text { products }\end{array}$} & \multirow{2}{*}{$\begin{array}{l}\text { Content (\%) } \\
\text { of } \\
\mathrm{PO}\left(\mathrm{NH}_{2}\right)_{3}\end{array}$} & \multirow{2}{*}{$\begin{array}{c}\text { Add-on } \\
(\%)\end{array}$} & \multicolumn{2}{|c|}{$\begin{array}{l}\text { Shrinkage (\%) } \\
\text { after laund. }\end{array}$} & \multirow{2}{*}{$\begin{array}{l}\text { Chlorine } \\
\text { damage } \\
\text { (rating) }\end{array}$} & \multirow{2}{*}{ Whiteness } \\
\hline & & & & Warp & Filling & & \\
\hline control & - & - & - & 13 & 7 & 5 & 140 \\
\hline-5 & 1 & 93 & 15 & 5 & 4 & 4 & 136 \\
\hline 5 & 3 & 90 & 15 & 5 & 4 & 4 & 134 \\
\hline 15 & 10 & 75 & 15 & 6 & 5 & 4 & 130 \\
\hline \multirow[t]{2}{*}{25} & 30 & 60 & 15 & 7 & 6 & 4 & 125 \\
\hline & $100^{a)}$ & 0 & 15 & 9 & 6 & 3 & 98 \\
\hline
\end{tabular}

a) See text for the preparation of methyl diamidophosphate.

Table 3 Effect of water in method A on fabric properties

\begin{tabular}{|c|c|c|c|c|c|c|c|}
\hline \multirow{2}{*}{$\begin{array}{c}\text { Water } \\
\text { added } \\
(\%)\end{array}$} & \multirow{2}{*}{$\begin{array}{c}\text { Content } \\
(\%) \text { of } \\
\mathrm{PO}\left(\mathrm{NH}_{2}\right)_{3}\end{array}$} & \multirow{2}{*}{$\begin{array}{c}\text { Content } \\
(\%) \text { of } \\
\left(\mathrm{NH}_{4}\right)_{3} \mathrm{PO}_{4}\end{array}$} & \multirow{2}{*}{$\begin{array}{l}\text { Add-on } \\
(\%)\end{array}$} & \multicolumn{2}{|c|}{$\begin{array}{l}\text { Shrinkage (\%) } \\
\text { after laund. }\end{array}$} & \multirow{2}{*}{$\begin{array}{l}\text { Chlorine } \\
\text { damage } \\
\text { (rating) }\end{array}$} & \multirow[t]{2}{*}{ Whiteness } \\
\hline & & & & Warp & Filling & & \\
\hline control & & & & 13 & 7 & 5 & 140 \\
\hline 0 & 93 & 0 & 15 & 5 & 4 & 4 & 134 \\
\hline 4.6 & 90 & 1 & 15 & 4 & 4 & 4 & 135 \\
\hline 9.2 & 88 & 3 & 15 & 3 & 3 & 4 & 134 \\
\hline 13.8 & 86 & 4 & 15 & 5 & 4 & 4 & 135 \\
\hline 18.4 & 82 & 4 & 15 & 5 & 4 & 4 & 134 \\
\hline
\end{tabular}

己縮合（風合い硬化の原因）を抑制し，アミド交換 反応を促進する反応条件を設定することが加工効果 を高めるのに必要と思われる。

\section{2 A 法リン酸アミド合成時の反応温度の 影響}

$\mathrm{A}$ 法の合成条件下では，塩化ホスホリルはメ夕ノ 一ルおよびアンモニアと競争的に反応する。低温に なるに従い, 競争反応の選択性は大きくなること, メタノールへのアンモニアの溶解度は増すこと, 激 しい発熱反応の制御は容易になることなどから，合 成反応を低温で行うことが好ましい，一方，エネル ギー的には反応を室温付近で進行させる方が有利で ある，そこで反応温度を変えて合成したリン酸アミ ドの加工剤適性を調べた（表 2).

反応温度が $5{ }^{\circ} \mathrm{C}$ 以下の場合, リン酸トリアミドが 95\%以上生成し, 加工布の性能むほぼ一定である. 反応温度が $10^{\circ} \mathrm{C}$ 以上の高い温度での製品はこの温度 が高くなるに従って加工布の洗濯収縮率は増加し白 度も低下した，從って，反応温度を $5^{\circ} \mathrm{C}$ 以下に保っ て A 法リン酸アミドの合成反応を行うことが望ま しい.

\section{3 リン酸アミド合成時の水分の影響}

メタノールは吸湿性があり, A 法でリン酸アミド を工業的に合成しようとする場合, 回収したメ夕ノ 一ルは吸湿して水分を含む可能性がある。水はアン モニアやメタノールと競争的に塩化ホスホリルと反 応すると予想されるため, リン酸アミド合成時の水 分の影響を明らかにしておくことが重要である。そ こで A 法で純メタノールの代わりに含水メタノー ルを用いてリン酸アミドを合成してその効果を検討 した (表 3). 添加水量が増加するとともにリン酸卜 リアミドの生成量は減少し, リン酸アンモニウムお よびポリリン酸誘導体が生成した。加工布の洗濯収 縮率は約 $9 \%$ の水添加量で最高となりそれ以上添加 すると逆に低下する．防縮性発現の主たる有効成分 がリン酸トリアミドであり，リン酸アンモニウムは 酸触媒として作用すると考えると表 3 の結果は説明 できる.

\section{4 防縮性に及ぼすリン酸アンモニウム塩の 触媒効果}

3.3の結果を基にリン酸アンモニウムを防縮加工 処理溶液に添加してその効果を検討した（表 4). リ ン酸トリアンモニウム塩は化学的に不安定なのでジ アンモニウム塩水溶液に当量のアンモ二ア水を加え て調整した．約 $10 \%$ のリン酸アンモニウム添加量ま 
Table 4 Effect of ammonium phosphate on fabric properties

\begin{tabular}{ccccc}
\hline \hline \multirow{2}{*}{$\begin{array}{c}\text { Ammonium } \\
\text { phosphate } \\
\text { added(\%) }\end{array}$} & $\begin{array}{l}\text { Shrinkage(\%) } \\
\text { after laund. }\end{array}$ & $\begin{array}{c}\text { Chlorine } \\
\text { damage } \\
\text { darp }\end{array}$ & Filling & Whiteness \\
(rating) & \\
\hline 0 & 5 & 4 & 5 & 134 \\
0.5 & 5 & 4 & 4 & 134 \\
1 & 5 & 4 & 4 & 134 \\
3 & 5 & 4 & 4 & 134 \\
5 & 5 & 4 & 4 & 134 \\
10 & 4 & 4 & $4-5$ & 135 \\
20 & 3 & 3 & $4-5$ & 136 \\
30 & 3 & 4 & $4-5$ & 138 \\
40 & 4 & 4 & $4-5$ & 138 \\
\hline
\end{tabular}

で洗濯収縮率，塩素障害および白度は向上した。こ の効果は $20 \%$ 程度の添加量で頭打ちとなった。表 3 に示したように,メタノールに水を $9.2 \%$ 添加して 合成した A 法リン酸アミド中にはリン原子の割合 で約 $3 \mathrm{~mol} \%$ のリン酸トリアンモニウムを含むが, その他にリン酸モノアミドおよびジアミドがそれぞ れ $5 \mathrm{~mol} \%$ および $7 \mathrm{~mol} \%$ 含まれていることが判明

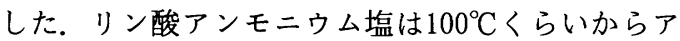
ンモニアを遊離して酸として作用することが知られ ている. 水の添加により副成したこれらのリン酸塩 が触媒作用を示すと考えられる。 アミノホスファゼ ン, リン酸アミドなどの合成の際に副成する塩化ア ンモニウムはクロロホルム中ジェチルアミン処理に よって除去することができる ${ }^{18)}$. しかし，塩化アン モニウムを除去したリンアミノ化物を加工骫として
利用するためには酸触媒を添加する必要がある，塩 化アンモニゥムを単独で綿布に含浸し, 熱処理する と白度の数值は表現できないほど黄変する。この場 合, 塩化アンモニウムにリン酸アンモニウムを添加 したもので熱処理すると白度はやや改善される。 リ ン酸アミドの熱縮合あるいはアミド交換反応によっ てアンモニアが放出される.このアンモニアが塩化 アンモニウムの解難で生成する塩化水素の作用を緩 和して, 綿布の黄変を防止していると考えられる.

\section{5 綿布の還元前処理による白度の改善}

上述のようにリンのアミノ化物による綿布の防縮 加工は極めて優れているが，加工布の白度の低下が 見られる場合が多い(19). 加工布の白度は一般に次亜 塩素酸塩にて処理する方法 ${ }^{20)}$ で改善されるが，今回 の加工布では不十分であった. 白度の低下は, 加工 剂自身の縮合による着色化合物の生成に起因すると あ考えられるが，絾維中に存在するカルボニル基と の縮合物に起因する可能性あある. リンターパルプ から調整された酸化セルロースの熱処理による白度 の低下は, 水素化ホウ素ナトリウム処理によって軽 減されることが知られている201.

そこで防縮加工処理前の加工布を水素化ホウ素ナ トリウム水溶液で処理した後に防縮加工した時の白 度の結果を表 5 に示す。この前処理によって加工布 のその他の物性はほとんど変わらなかった．実験 No.3〜11はいずれも市販品を用いた. 実験 No.1 は 加工剂を入れない処理，No.2 は加工剤中に含まれ

Table 5 Effect of sodium borohydride treatment on fabric whiteness ${ }^{()}$

\begin{tabular}{|c|c|c|c|c|c|c|c|c|c|c|c|}
\hline \multirow[t]{2}{*}{$\begin{array}{l}\text { Run } \\
\text { No. }\end{array}$} & \multirow{2}{*}{$\begin{array}{c}\text { Conc. } \\
\mathrm{NaBH}_{4} \\
(\mathrm{~g} / \mathrm{L})\end{array}$} & \multirow[t]{2}{*}{ of Reagent } & \multicolumn{3}{|c|}{$\begin{array}{l}\text { Cotton } \\
\text { whiteness } \\
\end{array}$} & \multicolumn{3}{|c|}{$\begin{array}{l}\text { Polynosic } \\
\text { whiteness }\end{array}$} & \multicolumn{3}{|c|}{$\begin{array}{l}\begin{array}{l}\text { Rayon } \\
\text { whiteness }\end{array} \\
\end{array}$} \\
\hline & & & Bef. & Aft. & Dif. & Bef. & Aft. & Dif. & Bef. & Aft. & Dif. \\
\hline 1 & 0 & - & 130 & 130 & 0 & 130 & 130 & 0 & 129 & 129 & 0 \\
\hline 2 & 0 & $\mathrm{NH}_{4} \mathrm{Cl}$ & 130 & d) & & 130 & d) & & 129 & d) & \\
\hline 3 & 0 & $\mathrm{AP}^{a)}$ & 130 & 120 & 10 & 130 & 117 & 13 & 129 & 114 & 15 \\
\hline 4 & 1 & $\mathrm{AP}$ & 130 & 125 & 5 & 130 & 123 & 7 & 129 & 121 & 8 \\
\hline 5 & 5 & $\mathrm{AP}$ & 130 & 127 & 3 & 131 & 125 & 6 & 129 & 122 & 7 \\
\hline 6 & 10 & AP & 131 & 128 & 3 & 131 & 125 & 6 & 130 & 123 & 7 \\
\hline 7 & 20 & AP & 131 & 128 & 3 & 131 & 126 & 5 & 130 & 124 & 6 \\
\hline 8 & 0 & $\mathrm{PA}^{b)}$ & 130 & 116 & 14 & 130 & 113 & 17 & 129 & 109 & 20 \\
\hline 9 & 1 & PA & 130 & 124 & 6 & 130 & 121 & 9 & 129 & 118 & 11 \\
\hline 10 & 5 & PA & 130 & 125 & 5 & 131 & 122 & 9 & 129 & 119 & 10 \\
\hline 11 & 10 & PA & 131 & 126 & 5 & 131 & 123 & 8 & 130 & 120 & 10 \\
\hline 12 & 20 & PA & 131 & 127 & 4 & 131 & 123 & 8 & 130 & 120 & 10 \\
\hline
\end{tabular}

a) Commercial aminophosphazene. b) Commercial phosphoryl amide

c) Fabric whiteness is shown before(Bef. ) and after (Aft.) the treatment and whiteness difference(Dif.) by the treatment.

d) Negative value 
る塩化アンモニウム $($ 約 $85 \mathrm{~g} / l)$ 水溶液のみで処理し た結果である．防縮加工剤中にはいずれあ実験 No. 2 之同程度の塩化アンモニゥムを含んでいるにもか かわらず白度の低下はNo.2より少なく, 塩化アン モニウムによる黄変がリンのアミノ化物により緩和 されていることが明白である.ささらに，水素化ホウ 素ナトリウム処理した加工布を用いると, 白度の低 下は著しく低減される. 水素化ホウ素ナトリウムの 濃度が $1 \mathrm{~g} / l$ でも顕著な効果を示し, 還元剤の濃度 を上げると白度もやや改善される.

各布帛別の防縮加工剂による白度の低下の度合い は, 普通レーヨンが最む大きく, 綿が最も小さい. 布帛のカルボニル基含有量の尺度の一つである銅価 についてみると，精練上がりで，それぞれ綿；0.1 $\mathrm{g}$, ポリノジック； $0.3 \mathrm{~g}$, 普通レーヨン; $0.6 \mathrm{~g}$ であ り, 銅価の大きいむの程白度の低下が大きくなって いる. 従って, 加工に伴う白度の低下は主として繊 維中に存在するカルボニル基との縮合物に起因する と推論される．銅価に相当する還元剂の量は理論的 には微量で十分であり，過剩の還元剂を用いても白 度の差異が生じるのは, 試薬が反応点に浸透拡散す る差異の繊維の構造および加工剂のキュアリング時 の再酸化の難易度などが各布帛の白度の保持の度合 いに影響しているものと考えられる。

\section{6 リン酸アミド類のセルロースとの反応}

\section{A エステル化}

リン酸アミド特にトリアミド（PTA）がセルロー ス (cell-OH) とアミド交換反応によりリン酸エス テルを生成することは知られている22)（式 1).

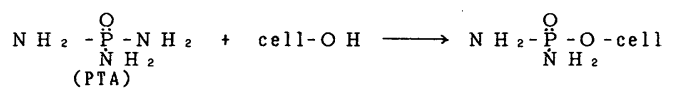

式 1 から PTA は 3 官能性化合物とみなせる.

リン酸アミドのアミド交換反応は 2 分子関与求核 置換反応 (SN2) よりは脱離一付加機構（式 2) で進

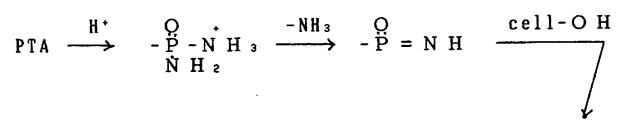

$$
\begin{aligned}
& -\stackrel{\mathrm{O}}{\stackrel{\mathrm{P}}{\mathrm{N}}-\mathrm{O}-\operatorname{cell}} \mathrm{H}_{2}
\end{aligned}
$$

行すると説明されている23.

脱離一付加機構で進行すると, PTA は 2 官能性 化合物とみなされる，すなわち，最初の 2 個のアミ ドは脱離一付加機構で速やかに， 3 番目のアミドは
SN2 反応で遅く反応すると考えられる．この反応式 から予測されるように，このエステル化反応は酸お よび塩基触媒の効果を受ける。リン酸アミド合成時 の副生成物塩化アンモニウムやリン酸誘導体, 有機 酸などがこの系の触媒として知られている。 リン酸 トリアミド自体塩基であり, 反応系から生じるアン モニアあ塩基触媒として作用すると考えられる.

リン酸ジアミド $(\mathrm{PDA})^{24)}$ はリン酸トリアミド合 成時あるいは貯蔵時に副成する.PTAより弱いが PDA が防縮効果を有することは我々も認めたが, その機構については明らかではない. 最近L. D. Quin $^{25)}$ は式 3 に示すアルキル N, Nージェチルホス

$\underset{\substack{\mathrm{O} \\ \mathrm{ADAP}}}{\stackrel{\mathrm{P}}{\mathrm{P}}-\mathrm{NE} \mathrm{t}_{2}} \rightarrow \mathrm{RO}-\stackrel{\mathrm{O}}{\mathrm{P}}=\mathrm{O} \stackrel{\text { cell-OH }}{\longrightarrow} \mathrm{R} \mathrm{O}-\stackrel{\mathrm{O}}{\mathrm{P}}-\mathrm{O}-\mathrm{O}$-cell (3) ホロアミダート (ADAP) がリン酸エステル化剂と して有効であることを報告している。この報告から 類推すると, PDA は式 4 に示す反応で 2 官能性工 ステル化剂（すなわち架橋剂）として作用すること

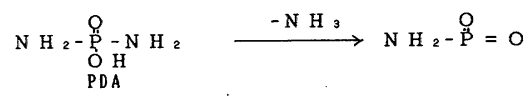

が期待される. 一方, Nielsen ${ }^{19)}$ はPTA 処理レーヨ ンのシュバイッァー試薬に対する溶解性から架橋反 応が生じていることを示唆している，以上の点を考 慮すると, PTA および PDA を多く含み, かつ触媒 として有用な酸および塩基を含む加工剂が望ましい といえる.

\section{B 架橋反応}

PTA (分子量95), トリメチロールメラミン (TMM, 分子量162), ジメチロールジヒドロキシェ チレン尿素 (DMDHEU, 分子量172), エチレングリ コール ジグリシジル エーテル (EGDGE, 分子 量142）はいずれあ天然繊維の防しわ加工剂として 知られている. 加工剂の縮合物による接着効果とと むに，繊維の架橋が防しわに寄与すると説明されて いる. TMM, DMDHEU, EGDGE のいずれも適切な 加工条件を用いれば普通レーヨンの防縮性をかなり 向上させるが, PTAのそれよりかなり劣る. しか し，PTA 加工布の防しわ性は必ずしも良好ではな い.また，同一綿原糸を用いても織物はあまり収縮 性を示さず, 編物は大きな収縮を示し, かつその防 縮加工の効果は加工滖によって絹と類似の傾向を示 $す^{111}$. 架橋鎖長など加工剂の種類や防縮機構につい て従来の考え方を見直す必要があると思われる. 


\section{C 加工布の風合いへの影蠤}

従来の繊維架橋剤 (TMM, DMDHEU, EGDGE など）は実際にかなり自己縮合しており，分子間の 共有結合架橋剤として反応する割合は少ないと考え られている.リン酸アミド類むこれらの架橋剤と同 じであるかどうかは不明である. リン酸トリアミド をトルエン中で加熱するとイミドジリン酸テトラア ミド（IDPT）およびその縮合同族体が生成する ${ }^{26)}$ (式 5).

$$
\underset{\mathrm{PTA}}{\longrightarrow} \underset{\mathrm{N}}{\stackrel{\mathrm{O}}{\mathrm{P}}-\mathrm{NHT}_{\mathrm{N}}-\stackrel{\mathrm{O}}{\mathrm{P}}-\mathrm{NH}_{2}}
$$

同様な機構で PDA はポリリン酸誘導体を生成す る.このような縮合ポリマーの生成とセルロースの 水酸基とのエステルの生成が競合していると思われ る. $\mathrm{A}$ 法および B 法リン酸アミドいずれを用いても 水洗後のレーヨン加工布は有効成分の約 $60 \%$ の重量 增加が認められる. A 法リン酸了ミド単独で $160^{\circ} \mathrm{C}$, $30 \mathrm{~min}$ 加熱した生成物は完全に水溶性である。一 方，B法リン酸アミドを同様な条件で加熱すると， 熱水に不溶の生成物が生ずる。この結果から，A 法 リン酸アミドを用いた加工では自己縮合物は水溶性 であり, 後処理で除去され, エステル化物のみが緎 維に残留して, 風合いの柔らかい加工布を与えると 推定される. IDPT およびその同族体の末端および 側鎖のアミド基は交換反応によるエステル化剂とし て作用すると予测される，従って, IDPT は多官能 性架橋剂と考えられる. しかし，防縮加工剂として はPTA の方がその熱縮合物より良好である.

\section{4.まとめ}

以上の結果からリン酸トリアミドの含有量の高い 製品にリン酸アンモニウムを添加した加工剂がセル ロース系繊維の防縮加工剂として優れており, さら にこの加工剂により耐塩素障害性, 白度, 柔軟性, 風合いいずれの点であ優れた加工効果が得られるこ
とが明らかとなった．加工布を水素化ホウ素ナトリ ウムで前処理すれば，白度はさらに改善された。

\section{文 献}

1) 川合英一; 紻消誌, G16，321（1975）

2）伊藤博; “新実用染色講座”, 色染社 (1987)

3）馬場俊彦，河波英二，末吉節二；加工技術，24，258（1989）

4) C. E. Pfefferd and H. C. Speel ; "Textile Chemicals and Auxiliaries", p. 120-124, John Wiley \& Sons, New York (1952)

5) D. D. Gagliardi and A. C. Nussle ; Am. Dyest. Rep., 39, 12 (1950)

6) L. A. Lantz and A. L. Morrison ; B. P. 480171

7) B. A. K. Andrews and B. S. Trask-Morrell ; Am. Dyest. Rep., 80, No. 8, 26 (1991)

8) C. M. Welch ; Text. Chem. Color., 22, No. 5, 13 (1990)

9) G. L. Drodmann ; Text. Chem. Color., 22, No. 11, 13 (1990)

10) C. M. Welch and B. A. K. Andrews ; Text. Chem. Color., 21, No. 2, 13 (1989)

11）大門優，笹倉忠雄，林良之；日本絾維機械学会第42回年次 大会講演要旨集, p. 151 (1989)

12）浅井紀夫，林良之，岡川逸郎；日虫雑，58，36（1989）

13）笹倉忠雄, 藤川達志, 林良之, 清水富男, 老田達生; 織学 誌, 49, No. 5, 254 (1993)

14）小林悦郎；日化, 1973，38

15）林良之, 樽井栄満, 谷口由希子, 清水富男, 老田達生, 浅 井紀夫，岡川逸郎，笹倉忠雄；織学誌，48，37（1992）

16) R. Clement and O. Koch; Chem. Ber., 87, 333 (1954)

17）笹倉忠雄, 浅井紀夫, 林良之; 未発表

18) M. Goehring and K. Niedenzu ; Chem. Ber., 89, 1768 (1959)

19) M. L. Nielsen; Text. Res. J., 27, 603 (1957)

20) H. Sihtola ; Papper Och. Tra., 45, 43 (1963)

21）日本化学会編; “実験化学講座”, 19巻, p. 206, 丸善 (1957)

22) P. Isaacs, M. Lewin, S. B. Sello, and C. V. Stevens; Text. Res. J., 44, 700 (1974)

23) R. S. Edmundson ; "Comprehensive Organic Chemistry", Vol. 2, Pergamon Press, London, p. 1261 (1979)

24) D. A. Palgrave ; "Mellor's Comprehensive Treatise On Inorganic And Theoretical Chemistry", Vol. 8, Suppl. 3, Longman, London, p. 766 (1971)

25) Chem. Eng. New ; Dec. 7, p. 31 (1992)

26) R. Klement, and H. Bar ; Z. Anorg. Allg. Chem., 300, 221 (1959) 